\title{
Plant-Pathogenic Bacteria as Biological Weapons - Real Threats?
}

\author{
J. M. Young, C. Allen, T. Coutinho, T. Denny, J. Elphinstone, M. Fegan, M. Gillings, T. R. Gottwald, \\ J. H. Graham, N. S. Iacobellis, J. D. Janse, M.-A. Jacques, M. M. Lopez, C. E. Morris, N. Parkinson, \\ P. Prior, O. Pruvost, J. Rodrigues Neto, M. Scortichini, Y. Takikawa, and C. D. Upper
}

\begin{abstract}
First author: Landcare Research, Private Bag 92170, Auckland, New Zealand; second and twenty-first authors: Department of Plant Pathology, University of Wisconsin, Madison 53706; third author: Forestry and Agricultural Biotechnology Institute, University of Pretoria, Pretoria 0002, South Africa; fourth author: Department of Plant Pathology, University of Georgia, Athens 30602-7274; fifth and fifteenth authors: Central Science Laboratory, Department for Food, Environment and Rural Affairs, Sand Hutton, York, YO41 1LZ, United Kingdom; sixth author: School of Molecular and Microbial Sciences, University of Queensland, St. Lucia, Queensland 4072, Australia; seventh author: Genes to Geoscience Research Centre, Department of Biological Sciences, Macquarie University, Sydney, NSW 2109, Australia; eighth author: U.S. Horticultural Research Laboratory, Agricultural Research Service, U.S. Department of Agriculture, Fort Pierce, FL 34945; ninth author: University of Florida, Citrus Research and Education Center, Lake Alfred 33850; tenth author: Università degli Studi della Basilicata, Dipartimento di Biologia, Difesa e Biotecnologie Agro-Forestali, 85100 Potenza, Italy; eleventh author: Department of Laboratory Methods and Diagnostics, Dutch General Inspection Service, P.O. Box 1115, 8300 BC Emmeloord, The Netherlands; twelfth author: UMR 077 PaVé, INRA, F-49071 Beaucouzé, France; thirteenth author: Instituto Valenciano de Investigaciones Agrarias, 46113 Moncada, Valencia, Spain; fourteenth author: UR 407 Pathologie Végétale, INRA, F-84140 Montfavet, France; sixteenth and seventeenth authors: CIRAD, UMR Peuplements Végétaux et Bioagresseurs en Milieu Tropical CIRAD-Université de la Réunion, Pôle de Protection des Plantes, 97410 Saint Pierre, La Réunion, France; eighteenth author: Laboratorio de Bacteriologia Vegetal, Centro Experimental do Instituto Biologico, Cx. Postal 70, 13001-970-Campinas, S.P., Brazil; nineteenth author: C.R.A.-Centro di Ricerca per la Frutticoltuta, 00134 Roma, Italy; and twentieth author: Faculty of Agriculture, Shizuoka University, Shizuoka, 422-8529, Japan.

Accepted for publication 4 June 2008.
\end{abstract}

\begin{abstract}
Young, J. M., Allen, C., Coutinho, T., Denny, T., Elphinstone, J., Fegan, M., Gillings, M., Gottwald, T. R., Graham, J. H., Iacobellis, N. S., Janse, J. D., Jacques, M.-A., Lopez, M. M., Morris, C. E., Parkinson, N., Prior, P., Pruvost, O., Rodrigues Neto, J., Scortichini, M., Takikawa, Y., and Upper, C. D. 2008. Plant-pathogenic bacteria as biological weapons - Real threats? Phytopathology 98:1060-1065.

At present, much attention is being given to the potential of plant pathogens, including plant-pathogenic bacteria, as biological weapons/ bioterror weapons. These two terms are sometimes used interchangeably and there is need for care in their application. It has been claimed that clandestine introduction of certain plant-pathogenic bacteria could cause such crop losses as to impact so significantly on a national economy and

suggested that they could cause serious public alarm, perhaps constituting a source of terror. Legislation is now in place to regulate selected plantpathogenic bacteria as potential weapons. However, we consider it highly doubtful that any plant-pathogenic bacterium has the requisite capabilities to justify such a classification. Even if they were so capable, the differentiation of pathogens into a special category with regulations that are even more restrictive than those currently applied in quarantine legislation of most jurisdictions offers no obvious benefit. Moreover, we believe that such regulations are disadvantageous insofar as they limit research on precisely those pathogens most in need of study. Whereas some human and animal pathogens may have potential as biological or bioterror weapons, we conclude that it is unlikely that any plant-pathogenic bacterium realistically falls into this category.
\end{abstract} thus constitute a threat to national security. As a separate outcome, it is
In recent years, acts of international terrorism have raised concerns that some microorganisms could be used as biological weapons, and the ensuing public discussion raised concerns about their potential to be used as weapons of mass destruction. (Various neologisms have been developed for the discussion of clandestine release of pathogens: agroterrorism, bioterrorism, biocrime, biowarfare, etc., and to microorganisms in this context: bioterror weapons, bioweapons, dual-use agents, and select agents. Some of these have obvious utility; others may obscure understanding. In this text, terms are used in their conventional sense. "Biological weapon" will be used to refer to diseasecausing microorganisms intended for clandestine introduction into a country, with hostile political intent. "Bioterror" refers to organisms with the capacity to instill significant levels of panic in society at large.) Two important aspects of such weapons are their

Corresponding author: J. M. Young; E-mail address: youngj@landcareresearch.co.nz

doi:10.1094/PHYTO-98-10-1060

(c) 2008 The American Phytopathological Society capacity to do extensive biological damage and to cause widespread fear or even terror among the human population. Human, animal, and plant pathogens have all been considered for their potential as epidemic-, epizootic-, and epiphytotic-causing agents to cause damage and to raise levels of social fear. Most attention has been paid to microbes that affect human populations (4) but this concern has been extended to plant pathogens, including plant-pathogenic bacteria $(8,14,15,19,23,24,26-28,33)$. Clearly, there is a need for careful assessment of the impact of deliberate clandestine introduction in terms of the economic harm through damage to animals or crops that might be caused, and the capacity of introduction to instill fear. There have been no documented cases of the successful use of plant pathogens to attack crops or other plants in the past (19) but legislation has nevertheless been enacted in the European Union and the United States of America to classify a number of plant-pathogenic bacteria as putative weapons.

Discussion of biological weapons as terror weapons revolves around suggestions that they have the capacity to cause fear, shock, or panic or have a psychological impact $(19,23,28)$. The 
concept is both highly emotive and influential but, in this context, there is no consensus as to what count as acts of terror. For instance, Casagrande (14) regards any clandestine biological attack, including environmental activism against any crop, as an act of terror.

The perception as to what a nation might consider constituting an international threat, and what are proper responses to it, is strongly influenced by cultural and political attitudes and by the historical perspective of that country. It follows that although there may be little dispute about the general characteristics of plant-pathogenic bacteria relevant to their consideration as potential biological weapons or bioterror weapons, specific definitions of them as potential biological weapons and appropriate responses to them may differ significantly. The discussion in this paper is set in an international context using examples from jurisdictions in which legislation governing biological weapons has already been enacted.

A general definition of plant-pathogenic bacteria recognizes any prokaryote that causes damage to a host plant species irrespective of the severity of the interaction. Most plant-pathogenic bacteria cause diseases that are of little or no economic importance (10). Some others cause damage that results in losses in crop yields, but these are usually tolerable. However, a small number of plant-pathogenic bacteria are capable of causing very serious damage to plants of considerable economic value. It is these pathogen-host combinations that are the subject of discussion here. If plant-pathogenic bacteria are to be defined and regulated as biological weapons, unambiguous criteria should be established to differentiate them from the majority of bacterial pathogens that clearly do not pose this threat. This is necessary in order to avoid regulation that would encumber routine research, distribution, and commercial activities.

An unintended consequence of listing plant-pathogenic bacteria as "select agents," because of their perceived potential as biological weapons could also be to restrict research that, in the long term, would more effectively mitigate serious crop damage by the pathogens than their regulation as biological weapons. The purpose of this paper is to consider (i) the criteria (or lack thereof) that might determine biological weapon status for plant-pathogenic bacteria; (ii) which plant-pathogenic bacteria, if any, fulfill such a category; and (iii) to consider the unintended consequences that such listings have in terms of the restriction of legitimate research that, in the long run, could be more effective in mitigating problems associated with plant-pathogenic bacteria.

A definition of a biological weapon. Considerable discussion has been given to the nature of biological weapons $(8,14,15$, 23,24,26-28,31-33) but there is no consensus as to a definition. Legislation has been introduced in the European Union $(5,18)$ and in the United States (2) to regulate organisms that might constitute a biological weapon threat. An Annex (6) to the European Union legislation refers to "dual-use" technology as ".... goods and technology developed for civilian uses, but which can be used for military purposes including for weapons of mass destruction or their means of delivery [our italics]" and bacteria with "dualuse" capability as "Bacteria, whether natural, enhanced or modified, either in the form of 'isolated live cultures' or as material which has been deliberately inoculated or contaminated with such cultures...." By the inclusion as "dual-use" technologies comparable with nuclear weapons, European Union legislation sets a very high threshold for selection. However, as will be seen, several plant-pathogenic bacteria are currently listed that do not meet such a standard. In the United States a list of "select agents," pathogens subject to legal regulation as biological weapons, has been created. The respective European Union and the United States lists do not include the same pathogens, nor do either sets of legislation specify the criteria for identifying and listing plant pathogens as biological weapons. In the wider literature, there are no agreed definitions of biological weapons or agreement as to their essential characteristics and this has led to the use of ambiguous terminology in discussion of the subject.

For the purposes of this discussion, we propose that, for a plant pathogen to be deemed a potential biological weapon, it must have the capacity to cause serious economic harm on a national scale. To be identified as an actual biological weapon, it must be intended for deliberate, clandestine introduction by a politically hostile adversary. The question as to whether such biological weapons can be described as bioterror weapons is treated separately.

Criteria for biological weapon damage. An assumption underpinning current legislation is that some plant-pathogenic bacteria are considered potential biological weapons because of their actual or potential capacity to cause devastating damage. There is no question that some plant-pathogenic bacteria cause serious damage, but to be considered a potential biological weapon, should not a pathogen be capable of causing serious loss to a crop that constitutes a significant food-stock, or a resource of economic significance to a national economy? Merely occasionally to reduce the yield of a regionally important crop cannot be considered adequate as a criterion. The minimum criterion should be that the economic viability of the crop is threatened by the resulting disease. We propose three criteria applied to crop loss, all of which must be fulfilled, before any plant-pathogenic bacterium could be considered as a potential biological weapon.

(i) It must be capable of causing devastating and sustained epidemic losses to a crop on a national scale. That is to say, although the crop loss may be confined to a region, the extent of loss must be such as to tend towards uneconomic yields; yields that are inadequate for a national purpose, or nationally important trade activity.

(ii) It must not already be present in the country or primary production area(s) under consideration.

(iii) The pathogen must cause loss that cannot be absorbed by substitution with another crop, or by obtaining the crop product from another source.

Several reports have attempted quantification of the likelihood that a plant pathogen can be a useful biological weapon, yet these are largely restricted to the pathogenic characteristics of the organism and give little analysis of crop loss $(19,23,28)$. None of these reports considers loss in relation to total production, commercial profitability, or to a national economy. Only in exceptional cases, and then only in general terms, is the impact of crop loss arising from epidemic damage considered in relation to the national crop and to the national economy. Yet this is crucial to the assessment of the impact of an intentional release. Strange and Scott (30) noted the difficulty of assessing crop loss, but without this information, discussion of pathogens as biological weapons is highly speculative.

Clandestine release. To be recognized as a biological weapon, there must be some basis for believing that the release was deliberate. For instance, the citrus greening pathogen $(\mathrm{Ca}$. Liberibacter spp.) and the soybean rust fungus (Phakosora pachyrizi) were on the U.S. Select List of potential biological weapons when they were found dispersed in major production regions. The possibility that these introductions were covert and intentional was not investigated in either case. It is difficult to specify what, in the absence of a claim of responsibility, would constitute proof of deliberate introduction.

An important difference between accidental and clandestine introduction is that the clandestine action, whether as industrial sabotage or political hostility, is very likely to involve multiple release points to enhance the likelihood of an epidemic and to make eradication more difficult. Notwithstanding this, there will be no difference in quarantine protocols and regulations aimed at preventing introductions by either path.

Clandestine release of any kind entails criminal acts that can be treated under existing criminal law. For example, animal viruses, 
such as those that cause swine fever, bluetongue, and foot and mouth disease of ungulates, have the potential for clandestine dissemination and the ability to cause considerable economic harm. It is not unimaginable that these or other pathogens could be used in acts of international industrial sabotage. Introduction could be with the intention of causing yield loss to reduce product competition, or to impose or to remove a non-tariff barrier. It is an open question if any of the activities, conducted with these intentions, would be described as release of a biological weapon.

Breeze (11) gives a thoughtful review of responses to accidental and clandestine introduction using the introduction of the foot and mouth virus into the United States as a model. Breeze concludes that clandestine introduction is easy, costs of eradication are high and the likelihood of successful eradication is low. Consequently, it is better to direct strategic effort at long-term planning and research towards effective control, rather than attempting to prevent illicit introduction by legislation. This model closely reflects the situation that applies to plant-pathogenic bacteria.

There is always a strong case for research aimed at refining and improving quarantine protocols and management measures against serious plant pathogens. However, current quarantine protocols, though perhaps in need for refinement, usually address adequately the most probable means by which unintentional or accidental release may occur. Is there, then, a need for regulation of plantpathogenic bacteria in a higher category-biological weaponthat invokes issues of national security in response? The study of strains designated as having biological weapon potential is only permitted in facilities with very high security levels. This can be expected to inhibit much research, most especially of studies of management of precisely those pathogens identified as being most harmful to economically significant crop plants $(12,13)$. It is beyond the scope of this discussion to attempt estimations of costs of compliance either at domestic and international levels, or of costs resulting from production loss because research and development is slowed or prevented, but it seems likely that they could be substantial.

Economic consequences of clandestine release. Little consideration has been given to the need to quantify the possible economic harm following the clandestine introduction of a pathogen. The following points are considered relevant.

- The diversification of agricultural resources means few countries that are the potential targets of clandestine introductions can be considered to be dependent on particular, locally grown crops either as primary food sources, or as industrial feed stocks.

- There are a very small number of plant-pathogenic bacteria that can be considered to have the potential to cause economic harm on a national scale. Devastating loss to a strategic crop caused by a bacterial pathogen has rarely, if ever, been recorded in a developed country where the principles of crop hygiene are widely understood. Rice (Oryza spp.), potato (Solanum tuberosum), wheat (Triticum spp.), and maize (Zea spp.) are examples of crops that, if they could be devastated on a national scale, could be considered targets for biological weapons, but there are no host-pathogen combinations likely to cause such damage.

- The majority of bacterial pathogens that have been identified as potential biological weapons are already endemic or introduced into most of the regions and countries in which their host crops are grown (10). There are few additional regions or countries in which their introduction might cause such economic damage as to confirm such identification.

- Reductions in yield of any particular crop usually affect only the associated industry and result in importation, price adjustments, and transfer to alternative food sources.

Several pathogens do cause loss to major crops. For instance, Xanthomonas campestris pv. musacearum and the phytoplasma causing coconut lethal yellows are devastating banana and coconut crops, respectively, as they spread through central Africa. However, there is no political context in which they can be con- sidered to be biological weapons, and there are no measures by which their movement between countries could be prevented, other than by routine but stringent quarantine protocols. $\mathrm{Ca}$. Liberibacter spp. and Xylella fastidiosa also cause heavy losses of citrus and often result in complete crop destruction. These latter two pathogens are discussed in more detail below.

Aetiological and epidemiological considerations. Consideration of the characteristics that regulate the infection and spread of plant-pathogenic bacteria is also essential to determining their potential as biological weapons. Those that appear to be relevant are assessed here.

- The simplest method of inoculum manufacture is as suspensions of comminuted infected plant material.

- Preparation of bacterial inoculum of most plant-pathogenic bacteria is within the capabilities of "kitchen" technology.

- Illicit international movement of most bacterial pathogens can be relatively easily achieved by smuggling cultures or naturally or artificially infected plant material.

- Release of most bacterial pathogens could be achieved by wound-inoculation using inoculum from cultures or from naturally or artificially infected plant material. $C a$. Liberibacter spp. and $X$. fastidios $a$ might be introduced and propagated in infected plant material, by grafting, or in their insect vectors. Determined efforts at clandestine introduction would probably be successful sooner or later.

- Extended incubation periods and inevitable delays in detection of plant disease usually mean that the likelihood of successful eradication, whether following accidental or clandestine introduction, is small (30).

- Clandestine introduction has a low probability of causing an immediate epidemic because natural environmental conditions only occasionally favor epidemic development.

- Pathogenic bacteria can be endemic but epidemic outbreaks are usually localized to regions of high crop density and to times when environmental conditions are conducive to widespread symptom development.

- Although bacterial pathogens may be widely dispersed, disease outbreaks are invariably sporadic, perhaps occurring at intervals of 2 to 3 years, and often at much greater intervals.

- Only very exceptionally, if ever, would sporadic epidemics in annual crops be likely to cause losses that would constitute a national threat. Crop devastation is more likely to occur in perennial crops in which disease progressively spreads and reduces crop productivity over several seasons.

- The most severe crop devastation is associated with systemic, fastidious xylem- or phloem-limited bacteria, such as $\mathrm{Ca}$. Liberibacter spp. and X. fastidiosa, whose epidemiology is determined, at least in part, by their insect vectors. However, their long latency periods and multi-year epidemic development allows time to anticipate economic impacts from crop losses, making them poor weapons.

- Although it may be possible to select for hypervirulent strains or to engineer greater virulence in selected pathogens by molecular methods, the capacity to enhance either infection or spread, dependent as these are on a multiplicity of environmental factors, is extremely difficult or impossible to manipulate.

Bacterial nomenclature and biological weapons. The European Union list of dual-use bacteria (5) includes Xanthomonas campestris pv. citri defined as "strains referred to as X. campestris pv. citri types A, B, C, D, and E, or otherwise classified as $X$. citri, X. campestris pv. aurantifolia [sic], or X. campestris pv. citrumelo." This nomenclature includes pathogens of citrus that are inconsequential in their effects, and pathogens unrelated to those occurring on citrus. Bacterial taxonomy is dynamic, the names of many plant-pathogenic bacteria having been revised, and it is understood that the names of others are in need of revision. Attempts to codify pathogens and responses to them cannot be done effectively by assuming a rigid nomenclature. The 
legislation has been enacted in the belief that bacterial names have descriptive properties; e.g., that a pathogen with the name citri is necessarily associated with the plant genus Citrus. This belief is mistaken (29). Although names are often derived from some character of the taxon when it was originally proposed, this carries no implication that all members of the taxon exhibit that character (34). The impact of this law is that one major European culture collection will only release $X$. axonopodis pv. 'citrumelo' (also called X. alfalfae subsp. citrumelonis or X. campetris pv. citri group E), the pathogen associated with the minor disease, citrus bacterial spot, with the most stringent permissions and with restrictions on further dissemination. Furthermore, a second major European culture collection will not release strains of $X$. citri subsp. malvacearum, specific to cotton, because of its species epithet. A recent analysis based on gene relationships $(3 ; \mathrm{N}$. Parkinson, unpublished data) indicates that a substantial number of pathovars at present allocated to $X$. axonopodis could, in a future nomenclatural revision of the species, be transferred to $X$. citri, bringing them within the framework of the legislation. Future revisions in bacterial nomenclature may therefore lead to regulation of the movement of strains for which restrictive legislation is inappropriate, with heavy criminal penalties for failure to comply with highly restrictive containment regulations. Legislation will also impede legitimate commercial and industrial applications of these bacteria.

Putative plant-pathogenic bacterial biological weapons. Below are brief notes about pathogens listed in the reports $(1,2,5,7)$ relevant to their consideration as potential biological weapons.

'Candidatus Liberibacter africanus', ' $\mathrm{Ca}$. L. americanus', and ' $C a$. L. asiaticus'. ' $C a$. L. africanus' and ' $C a$. L. asiaticus' are devastating phloem-limited systemic pathogens responsible for the citrus greening disease, now called huanglongbing (HLB). At present, 'Ca. L. africanus' is found in Africa, Arabia, Madagascar, Reunion, and Mauritius. ' $C a$. L. asiaticus' is found throughout Asia, South-East Asia, and Arabia, and has recently been reported in Brazil, and the state of Florida in the United States. ' $\mathrm{Ca}$. L. americanus' has been reported only in Brazil. Infected plants invariably deteriorate and eventually die. Once established, control appears to be impossible. The pathogens cannot be cultured and therefore dispersal and infection can only be carried out using infected plant material and by transmission via their psyllid vectors $(20,21)$.

Clavibacter michiganensis subsp. sepedonicus. This pathogen causes a serious systemic disease of potato and is difficult to control. Nevertheless, the application of modern hygiene measures allows the production of commercially profitable crops in countries in which the pathogen is present.

Erwinia amylovora. This pathogen of apple, pear, quince, loquat, and Rosaceous ornamentals appears to have variable affects on crops depending on local environmental conditions. It can cause serious losses in California and the United Kingdom. When first intorduced into New Zealand, it was regarded with concern, but since then it has proved to be a pathogen of nuisance value only (J. M. Young, unpublished data). It has been reported in most European countries where it is considered a limiting factor for growing some cultivars. There appears to be considerable variation in disease tolerance between cultivars and species (9).

Ralstonia solanacearum races 2 and 3. Compared with $R$. solanacearum race 1 , races 2 and 3 have relatively narrow host ranges of which banana and potato, respectively, are the most important crops. $R$. solanacearum race 2 causes damage on banana in tropical regions and $R$. solanacearum race 3 causes disease on potato, tomato, pepper, eggplant, and geranium in temperate regions (17). $R$. solanacearum race 2 could have a significant impact on banana production if it was introduced into regions where it had not previously been present. $R$. solana- cearum race 3 may be listed because of potential commercial impact of quarantine restrictions imposed on infected potato crops intended for export (19) rather than because of disease severity.

Xanthomonas albilineans. $X$. albilineans is ubiquitous in all regions where sugarcane is grown (10). It can cause serious local damage but the application of modern hygiene measures allows the routine production of commercially profitable crops.

Xanthomonas axonopodis pv. citri. Of xanthomonad pathogens of citrus, only that causing Asiatic or Oriental canker, variously named $X$. axonopodis pv. citri or $X$. citri subsp. citri, or $X$. campetris pv. citri group A, can cause serious losses to crops grown for juice and further losses in yield from cosmetic damage to crops grown for fruit (16). It is now present in all citrusproducing counties in Florida where economic crops are grown in spite of its presence. Other xanthomonad pathogens of citrus, named $X$. axonopodis pv. aurantifolii (or X. fuscans subsp. aurantifolii or $X$. campetris pv. citri groups B, C, and D) and $X$. axonopodis pv. citrumelo (or X. alfalfae subsp. citrumelonis or X. campetris pv. citri group E), can cause relatively minor losses in yield from cosmetic damage to crops grown for fruit $(20,22)$.

Xanthomonas oryzae pv. oryzae. X. oryzae pv. oryzae is the most serious bacterial disease of rice, sometimes causing serious epidemics and being responsible for widespread reduced rice yields (30). It is ubiquitous in all regions in Asia, where the crop is successfully grown as a staple food (10).

Xanthomonas oryzae pv. oryzicola. X. oryzae pv. oryzicola is endemic in areas of tropical rice production (10). It appears to cause less serious damage than $X$. oryzae pv. oryzae and, with the application of modern hygiene measures, does not cause major losses. This pathogen, but not $X$. oryzae pv. oryzae, was recently included on the U.S. Select List.

Xylella fastidiosa. X. fastidiosa is a devastating systemic xylemlimited pathogen that causes the disease variegated chlorosis of citrus. Infection of plants is only known to occur when vectors are present. The pathogen can be cultured and maintained with difficulty. Spread of the pathogen can be slowed, but not halted, by control of the insect vector and use of standard phytosanitary methods in the production of replants (25).

Of all the bacterial species listed above, only $\mathrm{Ca}$. Liberibacter spp. and $X$. fastidiosa, both pathogenic to citrus, might be considered to fulfill the criteria proposed for biological weapons. The citrus crop is the basis of juice and fruit industries that are so large that serious damage to them might have significant consequences for those economies in the United States and Europe where the pathogen is not already present.

Psychological consequences of clandestine release (bioterror). Several reports suggest that release of plant pathogens as biological weapons could cause yield losses leading to fear, shock, or panic or have a psychological impact $(19,23,28)$. It is this language and these concepts that imply that they may be considered to be bioterror weapons. We are not aware of any plant-pathogenic bacterium with the capacity to do damage likely to have the psychological consequences suggested. For example, the accidental release and rapid dissemination of the foot and mouth virus on farms in the United Kingdom in 2001 could hardly have done more damage if it had been introduced clandestinely, yet the popular concern, though widespread, was largely allayed by temperate reassurances of its probable effects. It is true that a willful, destructive act carries with it a threat not associated with accidental introduction, but no plant-pathogenic bacterium has the capacity to do such acute damage following introduction into a region or country for the first time as to generate fear. The plant-pathogenic bacteria that cause the greatest losses, $\mathrm{Ca}$. Liberibacter spp. and $X$. fastidiosa, require several years to achieve their full economic impact. In this circumstance, it cannot be accepted that the terms fear, shock, or panic could be applied to their effect. In short, there is no bacterial plant pathogen with the capacity to cause such damage as to instill public fear or alarm. 
Some literature is presented in general terms in which the relative threats of biological weapon release of human pathogens and agricultural pathogens are not clearly differentiated, therefore exaggerating the latter threats (14). It should be a matter for concern when speculation involving worst-case epidemic and damage scenarios replaces temperate realistic assessments of probable consequences. For instance, Wheelis et al. (32) consider that any attack on agricultural resources, including release of animal pathogens, would be unlikely to cause serious alarm.

Conclusions. The criterion that would justify recognition of any known plant-pathogenic bacterium as a biological weapona bacterium not already present in a country or region and whose clandestine introduction by a hostile adversary in a declared or undeclared war could do significant harm to a national economy and thus pose a threat to national security-can only be considered relevant to very few bacteria. A consideration of the bacteria already listed as potential biological weapons shows few that are likely to pose the kind of acute or chronic threats associated with the concept of biological weapon release. Only strains of $\mathrm{Ca}$. Liberibacter spp. and X. fastidiosa, pathogenic to citrus, might be considered as possible, though doubtful, candidates.

The application of less stringent criteria would mean that research and distribution of plant-pathogenic bacteria that pose a lesser threat will be regulated by national security legislation. This will seriously and unnecessarily inhibit research on these pathogens and deny the rewards of such research.

Because most plant-pathogenic bacteria can be propagated as pure cultures or in infected material with relative ease, determined attempts at clandestine introduction are likely to succeed whatever legislative barriers on the movement of pathogenic material are in place. These barriers are already sufficient to address nonclandestine introductions. More restrictive regulation of movement of bacterial strains in culture can only constrain legitimate exchanges.

Even if pathogens did fulfill the proposed criteria for a biological weapon, it is not clear that regulation in terms of national security is the best approach to controlling them. Longstanding quarantine legislation in most jurisdictions already restricts the movement of pathogenic bacterial strains and provides responses that will mitigate the impact of accidental, as well as clandestine, release. There is an urgent need for critical consideration as to whether the likelihood of clandestine release can be significantly reduced by even more restrictive quarantine legislation. Legislation that does not critically consider realistic scenarios is likely to do more harm than any plausible biological threat, acting as a gratuitous barrier both to research on control measures of these most serious pathogens, and to the exchange of organisms for potentially useful purposes.

In addition, some legislation restricts bacteria simply on the basis of their names, without consideration of their actual or potential threat. The consequence of this misunderstanding is that bacteria that present little or no conceivable threat in terms of national security are restricted unnecessarily, and noncompliance with regulations governing their movement and use may incur extraordinary penalties.

Some reports give undue emphasis to plant-pathogenic bacteria as bioterror weapons, and in so doing may induce concern or even fear among those unfamiliar with them that is wholly unwarranted. To imply that plant-pathogenic bacteria can be bioterror weapons is greatly to exaggerate their capacity to cause harm and hence fear.

The threat of biological weapon use must be given careful consideration. There are human and animal pathogens that could be devastating if deliberately spread. However, when plant pathogens are compared with human and animal pathogens, it is clear that the latter present a far greater threat as potential biological weapons. It is unlikely that any plant-pathogenic bacterium can be justified realistically as a biological weapon and, considered overall, attempts to control them as such by legislative means are counter-productive.

The critical perspective presented in this paper, focused on plant-pathogenic bacteria, might fruitfully be applied to the assessment of fungal and viral pathogens to determine whether any of these merit reconsideration as biological weapons.

\section{ACKNOWLEDGMENTS}

Publication was partly supported by an NRI-CSREES Plant BioSecurity grant (2007-55605-17843) to C. Allen.

\section{LITERATURE CITED}

1. Ad Hoc Group. 1997. Ad Hoc Group of the States Parties to the Convention on the Prohibition of the Development, Production and Stockpiling of Bacteriological (Biological) and Toxin Weapons and on their Destruction. BWC/Ad Hoc Group 38, Rolling Text, Annex I.

2. Agricultural Bioterrorism Protection Act of 2002. 2002. Possession, use and transfer of biological agents and toxins. Department of Agriculture, Animal and Plant Health Service. United States Federal Register 67(240):76926-76938

3. Ah-You, N., Gagnevin, L., Grimont, P. A. D., Brisse, S., Nesme, X., Chiroleu, F., Bui Thi Ngoc, L., Jouen, E., Lefeuvre, P., Vernière, C., and Pruvost, O. Polyphasic characterization of xanthomonads pathogenic to Anacardiaceae and their relatedness to species of Xanthomonas. Int. J. Syst. Evol. Microbiol. (In Press).

4. Atlas, R. M. 2002. Bioterrorism: from threat to reality. Annu. Rev. Microbiol. 56:167-185.

5. Anonymous. 2002. American Phytopathological Society: The first line of defense. http://www.apsnet.org/media/BiosecurityWhitepaper2-02.pdf.

6. Anonymous. 2006. Annex I. List of dual-use items and technology. Official Journal of the European Union, 13.3.2006, L 74/2. www. trade.ec.europa.eu/doclib/docs/2006/december/tradoc_131576.pdf.

7. Australia Group. 2005. List of plant pathogens for export control. Published online by the Australia Group. http://www.australiagroup.net/ en/plants.html.

8. Beale, J., Brown, W., Cline, M., Cook, J., Desjardins, A., Fletcher, J., Leach, J., Lévesque, A., Madden, L., and Schaad, N. 2002. Crop biosecurity and countering agricultural bioterrorism: Responses of The American Phytopathological Society. APSnet Feature. Published online by The American Phytopathological Society, St. Paul, MN.

9. Bonn, W. G., and van de Zwet, T. 2000. Distribution and economic importance of fire blight. Pages 37-54 in: Fire Blight-The Disease and Its Causative Agent, Erwinia amylovora. J. L. Vanneste, ed. CABI Publishing, Wallingford, UK.

10. Bradbury, J. F. 1986. Guide to Plant Pathogenic Bacteria. CAB International, Kew, UK.

11. Breeze, R. 2004. Agroterrorism: Betting far more than the farm. Biosecur. Bioterror. 2:251-264.

12. Callaway, E. 2007. Plant-disease controls sap outbreak responses. Nature 450:596.

13. Callaway, E. 2008. The green menace. Nature 452:148-150.

14. Casagrande, R. 2000. Biological terrorism targeted at agriculture: the threat to U.S. national security. Nonproliferation Rev. 73:92-105.

15. Cupp, O. S., Walker, D. E., and Hillison, J. 2004. Agroterrorism in the U.S.: Key security challenge for the 21 st Century. Biosecur. Bioterror. 2:97-105.

16. Das, A. K. 2003. Citrus canker-A review. J. Appl. Hortic. 5:52-60.

17. Denny, T. P. 2006. Plant pathogenic Ralstonia species. Pages 573-644 in: Plant-Associated Bacteria. S. S. Gnanamanickam, ed. Springer Publishing, Dordrecht, The Netherlands.

18. EU Council Regulation. 2000. Council Regulation (EC) No. 1334/2000 of 22 June 2000, http://eur-lex.europa.eu/LexUriServ/LexUriServ.do?uri= CELEX:32000R1334:EN:HTML

19. Fletcher, J., Bender, C., Budowle, B., Cobb, W. T., Gold, S. E., Ishimaru, C. A., Luster, D., Melcher, U., Murch, R., Scherm, H., Seem, R. C., Sherwood, J. L., Sobral, B. W., and Tolin, S. A. 2006. Plant pathogen forensics: Capabilities, needs, and recommendations. Microbiol. Mol. Biol. Rev. 70:450-471.

20. Gottwald, T. R. 2007. Citrus canker and citrus huanglongbing. Two exotic bacterial diseases threatening the citrus industries of the Western Hemisphere. Outlooks Pest Manag. 18:274-279.

21. Gottwald, T. R., da Graca, J. V., and Bassanezi, R. B. 2007. Citrus huanglongbing: The pathogen and its impact. Published online by Plant Health Progress doi:10.1094/PHP-2007-0906-01-RV.

22. Gottwald, T. R., Graham, J. H., and Schubert, T. S. 2002. Citrus canker: The pathogen and its impact. Published online by Plant Health Progress 
doi:10.1094/PHP-2002-0812-01-RV.

23. Latxague, E., Sache, I., Pinon, J., Andrivon, D., Barbier, M., and Suffert, F. 2007. A methodology for assessing the risk posed by the deliberate and harmful use of plant pathogens in Europe. Bull. OEPP/ EPPO Bull. 37:427-435.

24. Madden, L. V., and Wheelis, M. 2003. The threat of plant pathogens as weapons against crops. Annu. Rev. Phytopathol. 41:155-176.

25. Purcell, A. H., and Hopkins, D. L. 1996. Fastidious xylem-limited plant pathogens. Annu. Rev. Phytopathol. 34:131-151.

26. Roger, P., Whitby, S., and Dando, M. 1999. Biological warfare against crops. Sci. Am. 280:70-75.

27. Schaad, N. W., Shaw, J. J., Vidaver, A., Leach, J., and Erlick, B. J. 1999. Crop biosecurity. APSnet Feature. Published online by The American Phytopathological Society, St. Paul, MN.

28. Schaad, N. W., Abrams, J., Madden, L. V., Frederick, R. D., Luster, D. G., Damsteegt, V. D., and Vidaver, A. K. 2006. An assessment model for rating high-threat crop pathogens. Phytopathology 96:616-621.

29. Sneath, P. H. A. 2005. Bacterial nomenclature. Pages 83-88 in: The Proteobacteria: Bergey's Manual of Systematic Bacteriology, vol. 2a. 2nd ed. D. J. Brenner, N. T. Krieg, J. T. Staley, and G. M. Garrity, eds. Springer-Verlag, New York.

30. Strange, R. N., and Scott, P. R. 2005. Plant disease: A threat to global food security. Annu. Rev. Phytopathol. 42:83-116.

31. Suffert, F. 2003. L'utilisation volontaire d'agents phytopathogènes contre les cultures. L'agroterrorisme et ses conséquences sur notre approche de la lutte contre les maladies des plantes. Phytoma 563:8-12.

32. Wheelis, M., Casagrande, R., and Madden, L. V. 2002. Biological attack on agriculture: Low tech, high-impact bioterrorism. Bioscience 52:569-576.

33. Whitby, S. M. 2001. The potential use of plant pathogens against crops. Microbes Infect. 3:73-80.

34. Young, J. M. 2000. Suggestions for avoiding on-going confusion from the Bacteriological Code. Int. J. Syst. Evol. Microbiol. 50:1687-1689. 